\title{
MENINGKATKAN KEMAMPUAN GURU DALAM MENYUSUN KISI-KISI SOAL DENGAN METODE PENDAMPINGAN POLA “OCF”
}

\author{
Susiatin \\ SDN Yanti Kec. Jogoroto, Kabupaten Jombang \\ Email: susi.april2@gmail.com
}

\begin{abstract}
The purpose of this study is (1) to get an overview of the implementation of the OCF pattern of mentoring methods to improve the ability of teachers in compiling the question grid. (2) obtain information on improving the ability of teachers to compile the question grid using the OCF pattern of assistance. This study uses a Kemmis design research flow consisting of four steps, namely: planning, implementation, observation and reflection. Whereas the design of activities uses the mentoring method with observ, critizize, and fix-it patterns, which are carried out in an integrated manner. Data is collected through a review instrument then the results are processed as conclusions. The results of the study are a description of the teacher's achievement value in writing the grid covering eight aspects of the criteria of a good question grid after taking action with the OCF technical assistance method. The teacher achievement scores in preparing the lattice in the pre-cycle is 69 to 81 in cycle I and rises to 87 in cycle II.
\end{abstract}

Keywords: Capability, Evaluation Grid, OCF

\begin{abstract}
Abstrak: Tujuan penelitian ini adalah (1) memeroleh gambaran pelaksanaan metode pendampingan pola OCF untuk meningkatkan kemampuan guru dalam menyusun kisi-kisi soal. (2) memeroleh informasi peningkatan kemampuan guru dalam menyusun kisi-kisi soal menggunakan metode pendampingan pola OCF. Penelitian ini menggunakan alur penelitian rancangan Kemmis yang terdiri atas empat langkah, yakni: perencanaan, pelaksanaan, observasi dan refleksi. Sedangkan rancangan kegiatannya menggunakan metode pendampingan dengan pola kegiatan observe, critizize, dan fix-it, yang dilaksanakan secara terintegrasi. Data dikumpulkan melalui instrument telaah kisi-kisi kemudian hasilnya diolah sebagai bahan pengambilan kesimpulan. Hasil penelitian berupa gambaran nilai capaian guru dalam menulis kisi-kisi mencakup delapan aspek kriteria kisi-kisi soal yang baik setelah dilakukan tindakan dengan metode pendampingan pola OCF. Adapun nilai capain guru dalam menyusun kisi-kisi pada pra siklus adalah 69 Menjadi 81 pada siklus I dan naik menjadi 87 pada siklus II.
\end{abstract}

Kata Kunci: Kemampuan, Kisi-Kisi, Pola OCF

Peraturan Presiden Nomor 2 tahun 2015 Tentang Rencana Pembangunan Jangka Menengah Nasional 2015-2016 mengamanatkan, bahwa di samping tersedianya kurikulum yang handal, salah satu aspek terpenting dalam upaya menjamin kualitas layananan pendidikan adalah menyediakan sistem penilaian yang komprehensif sesuai dengan standar nasional pendidikan yang telah ditetapkan. Dalam Kamus Besar Bahasa Indonesia, komprehensif memiliki arti luas dan lengkap (tentang ruang lingkup atau isi). Penilaian yang komprehensip harus mampu mancakup berbagai aspek sikap, pengetahuan, dan keterampilan (Azwar, 2015).

Peraturan Menteri Pendidikan Dan Kebudayaan Republik Indonesia No. 23 Tahun 2016 Tentang standar Penilaian menyebutkan bahwa penilaian adalah proses pengumpulan dan pengolahan informasi untuk mengukur pencapaian hasil belajar peserta didik. Beberapa ahli menafsirkan pengertian penilaian sebagai berikut: (Arikunto, 2005) menyebutkan bahwa penilaian adalah mengambil suatu keputusan terhadap sesuatu dengan ukuran baik dan buruk. (Widoyoko, 2012) mendefinisikan penilaian ialah sebagai kegiatan menafsirkan data hasil pengukuran 
berdasarkan kriteria dan aturan-aturan tertentu. Dari beberapa pengertian diambil kesimpulan bahwa penilaian merupakan serangkaian kegiatan yang sistematis dan berkesinambungan untuk memeroleh data dan informasi tentang proses dan hasil belajar peserta didik. Dalam perannya penilaian digunakan untuk mengumpulkan data dan informasi tentang kekuatan dan kelemahan dalam proses pembelajaran sehingga dapat dijadikan dasar untuk pengambilan keputusan dan perbaikan proses pembelajaran berikutnya (Manullang, 1996).

Ada beberapa langkah yang harus dilakukan agar alat penilaian dapat tersusun dengan baik, yakni: (1) Mengkaji kurikulum dan buku pelajaran untuk menentukan ruang lingkup pertanyaan tidak menyimpang dari materi yang diajarkan. (2) Merumuskan tujuan pembelajaran untuk memastikan target kemampuan yang akan diukur. Tujuan ini dirumuskan secara operasional, artinya dapat diukur dengan alat penilaian yang biasa digunakan. (3) Membuat kisi-kisi alat penilaian. Kisi-kisi hendaknya mampu menampakkan kemampuan yang akan diukur, proporsinya, lingkup materi yang diujikan, tingkat kesulitan soal, jenis alat penilaian yang digunakan, jumlah soal atau pertanyaan, dan perkiraan waktu yang diperlukan untuk mengerjakan soal tersebut. (4) Menyusun soal berdasarkan kisi-kisi yang ada. (5) membuat kunci jawaban dan pedoman pensekoran (Handoko, 1995).

Hasil penilaian harus memberikan hasil yang dapat diterima oleh semua pihak, pesertadidik, sekolah, masyarakat, maupun pemerintah. Hasil penilaian yang akurat hanya akan dihasilkan dari instrument yang akurat pula. Begitu pentingnya instrument penilaian sebagai jaminan kualitas soal, pemerintah melalui Permendikbud No. 23 Tahun 2016 mengemukakan beberapa prinsip dalam menyusun instrument penilaian yaitu: (1) sahih, maksudnya adalah instrumen yang disusun benar-benar mengukur apa yang seharusnya diukur, (2) objektif, maksudnya adalah instrumen penilaian yang dibuat hendaknya menghindari kemungkinan sikap subyektifitas penilai muncul, (3) adil, maksudnya adalah instrument penilaian yang dibuat saat digunakan tidak menguntungkan atau merugikan peserta didik karena perbedaan latar belakang agama, suku, budaya, adat istiadat, status sosial ekonomi, gender, dan hal-hal lain. Perbedaan hasil penilaian semata-mata harus dise-babkan oleh berbedanya capaian belajar peserta didik pada kompetensi yang dinilai, (4) terpadu, maksudnya bahwa penilaian oleh pendidik merupakan salah satu komponen yang tak terpisahkan dari kegiatan pembelajaran. Karena itu penilaian tidak boleh terlepas apalagi melenceng dari pembelajaran. Penilaian harus mengacu pada proses pembelajaran yang dilakukan, (5) terbuka, maksudnya prosedur penilaian dan kriteria penilaian harus terbuka, jelas, dan dapat dike-tahui oleh siapapun. Dalam era keterbukaan seperti sekarang, pihak yang dini-lai dan pengguna hasil penilaian berhak tahu proses dan acuan yang digunakan dalam penilaian, sehingga hasil penilaian dapat diterima oleh siapapun (6) menyeluruh dan berkesinambungan, maksudnya penilaian oleh pendidik mencakup semua aspek kompetensi dengan menggunakan berbagai teknik penilaian yang sesuai, untuk memantau perkembangan kemampuan peserta didik atau peserta didik. Instrumen penilaian yang digunakan, secara konstruk harus merepresentasikan aspek yang dinilai secara utuh. (7) Penilaian dilakukan secara berencana dan bertahap dengan mengikuti langkah-langkah baku. Penilaian sebaiknya diawali dengan pemetaan. Dilakukan identifikasi dan analisis KD (kompetensi dasar), dan indikator ketercapaian KD. Berdasarkan hasil identifikasi dan analisis tersebut dipetakan teknik penilaian, bentuk instrumen, dan waktu penilaian yang sesuai, (8) beracuan kriteria, maksudnya bahwa Penilaian pada kurikulum berbasis kompetensi menggunakan acuan kriteria. Artinya untuk menyatakan seorang peserta didik telah kompeten atau belum bukan dibandingkan terhadap capaian teman-teman atau kelompoknya, melainkan dibandingkan terhadap kriteria minimal yang ditetapkandan, (9) akuntabel, maksudnya adalah bahwa penilaian dapat dipertanggungjawabkan, baik 
dari segi teknik, prosedur, maupun hasilnya (Wardani, 2013).

Prinsip-prinsip di atas mendasari pemikiran bahwa penilaian memiliki peran yang sangat penting sehingga penyusunan instrumennya juga harus mengacu pada kaidah-kaidah yang benar. Kaidah penyusunan instrumen penilaian merujuk pada aturan yang ditetapkan pemerintah melalui permennya dan diterjemahkan sebagaimana tujuan yang akan dicapai. Untuk menghasilkan instrument yang berkualitas dengan mengacu pada kaidah, maka penyusunannya perlu dilakukan melalui prosedur benar sebagaimana ditetapkan pemerintah melalui Panduan Penilaian Sekolah Dasar/Madrasah tahun 2016 dimana penilaian proses belajar dan hasil belajar yang harus dilakukan melalui prosedur: (1) menetapkan tujuan penilaian dengan mengacu pada RPP yang telah disusun; (2) menyusun kisi-kisi penilaian; (3) membuat instrumen penilaian berikut pedoman penilaian; (4) melakukan analisis kualitas instrumen; (5) melakukan penilaian; (6) mengolah, menganalisis, dan menginterpretasikan hasil penilaian; (7) melaporkan hasil penilaian; dan (8) memanfaatkan laporan hasil penilaian (Thoha, 2004).

Pemerintah menetapkan tahapan penilaian sebagai bentuk pemberian jaminan kualitas evaluasi pembelajaran agar pendidik mampu melakukan pembelajaran dengan kualitas yang diharapkan (Astuti, Slameto, \& Y, 2017; Fauziah, 2011; Suhandani \& Julia, 2014). Berhasil tidaknya pembelajaran dapat dilihat dari hasil penilaian. Sebaliknya, jika instrumen penilaian yang digunakan tidak disusun sesuai dengan prinsip sebagaimana disebutkan di atas maka keberadaannya diragukan sehingga hasilnya juga diragukan. Hal ini akan bertentangan dengan tujuan penilaian yang salah satunya adalah untuk memperbaiki kualitas pembelajaran. Sebagaimana disampaikan oleh (Mardapi, 2012), menjelaskan bahwa salah satu cara memperbaiki kualitas pendidikan dalam hal proses pembelajaran adalah melalui perbaikan kualitas evaluasi.
Ada beberapa hal penting yang perlu dilakukan oleh guru dalam melakukan penilaian yaitu menyusun perangkat tes yang standar (Listyawati, 2012). Perangkat yang dimaksud meliputi kisi-kisi soal, soal, kunci jawaban beserta rubrik penilaiannya. Soal tes yang baik disusun berdasarkan kisi-kisi yang ada. Kisi-kisi (test blue-print atau table of specification) didefinisikan sebagai matrik informasi yang dapat dijadikan pedoman untuk menulis dan merakit soal menjadi tes. Tujuan penyusunannya adalah untuk menentukan ruang lingkup dan tekanan penilaian yang setepat-tepatnya, sehingga dapat menjadi petunjuk dalam menulis soal (Fahdini, Mulyadi, Suhandani, \& Julia, 2014; Leksono, Rustaman, \& Redjeki, 2013; Werdayanti, 2008). Dengan menggunakan kisi-kisi, penulis soal akan dapat menghasilkan soal-soal yang sesuai dengan tujuan tes dan perakit tes akan mudah menyusun perangkat tes. Kisi-kisi akan mampu menuntun guru dalam menyusun soal tes sesuai dengan tujuan yang diharapkan. Kisi-kisi juga akan membawa guru pada batas kemampuan apa soal dibuat. Dengan kisi-kisi yang terstandar, soal yang dibuat guru akan memiliki kualitas yang sama dimanapun soal tes dibuat (Nurgiyantoro, 2004). Jika semua soal yang dibuat oleh guru sesuai dengan kisikisi maka kualitas soal akan semakin baik. Untuk mewujudkan kondisi tersebut tentu tidak mudah, karena tuntutannya adalah guru harus mampu menyusun kisi-kisi dengan baik.

Kepala sekolah melalui tugas supervisi akademiknya perlu memastikan bahwa harapan guru untuk meningkat kompetensinya dapat terwujud. Dalam hal ini peran supervisi kepala sekolah menjadi taruhan dalam memberdayakan dan meningkatkan kualitas guru. (Hartanto \& Purwanto, 2019) menyatakan bahwa pembelajaran yang berkualitas hanya dapat dilaksanakan oleh guru yang berkualitas pula. Pembelajaran berkualitas juga ditentukan oleh kualitas perangkat penilaian yang digunakan. Dari pelaksanaan supervisi akademik ini kepala sekolah dapat mengetahui kelemahan guru khususnya dalam menyusun perangkat penilaian yang dalam hal ini salah satunya adalah kisi-kisi soal. 
Ada banyak aspek yang menjadi kendala bagi guru dalam menyusun kisi-kisi sehingga kisi-kisi buatan guru krang berkualitas (Ananda \& Fadhilaturrahmi, 2018; Ismail, 2010; Kartowagiran, 2011). Guru masih belum memahami bagaimana memilih Kompetensi Dasar yang benar. Banyak indikator yang memuat materi yang tidak seharusnya. Masalah lain adalah banyak ditemukan indikator pada kisi-kisi yang tidak berkembang, artinya hanya dapat dibuat satu soal saja. Banyak juga ditemukan dalam satu kisi-kisi tidak memuat indikator kunci sehingga jika kisi-kisi benar digunakan, soal tidak mengukur capaian Kompetensi Dasar. (Wardhani, 2008) mengemukakan bahwa indikator kunci memiliki sasaran untuk mengukur ketercapaian standar minimal dari KD. Jika indikator kunci tidak ditulis dalam kisikisi maka soalnya juga tidak dapat digunakan mengukur capaian minimal KD. Banyak juga ditemukan kesalahan dalam pelevelan, sehingga pada tingkat kognitif apa anak akan dikur menjadi tidak jelas. Masih banyak juga ditemukan pembobotan soal yang kurang tepat, bahkan terbalik. Soal yang semestinya bobotnya lebih banyak justru malah dibobot sedikit (Supriadi, 2009). Masalah yang lain adalah susunan indikator soal tidak mencerminkan gradasi soal mudah ke sedang, sederhana ke komplek.

Sebagaimana terjadi saat pengamatan pada instrumen penilaian yang dilakukan di SDN Yanti Kecamatan Jogoroto, dari keseluruhan soal yang dibuat oleh guru, 82\% tidak disertai kisi-kisi. Beberapa kisis-kisi yang berhasil dianalisa kepala sekolah menunjukkan bahwa kisi-kisi yang dibuat guru kurang sesuai. Hal ini dibuktikan banyaknya indikator soal yang menyimpang dari tujuan pembelajaran. Berdasarkan analisa bahwa jika soal disusun dari kisi-kisi yang salah akan menhgasilkan soal yang salah. Soal yang salah sudah pasti tidak dapat digunakan untuk mengukur capaian kompetensi dasar yang diharapkan. Beberapa masalah pokok yang menyebabkan minimnya kisi-kisi yang dimiliki guru-guru adalah karena ketidakpahaman. Oleh karena itu, untuk mendorong guru agar termotivasi menyusun kisi-kisi pada instrument penilaiannya perlu dilakukan pendampingan. Guru perlu mendapat pengetahuan cukup tentang materi penyusunan kisi-kisi yang baik.

Permasalahan di atas mendorong peneliti untuk mengembangkan sebuah pola pendampingan yang memungkinkan guru belajar menyusun kisi-kisi melalui kegiatan mengamati model, bertindak kritis, dan melakukan penyempurnaan. Pola ini merupakan pola berurutan yang ditulis dalam bahasa asing yaitu Observe, Criticize, Fix It (OCF). OCF merupakan pola pelaksanaan pendampingan dengan menerapkan langkahlangkah yang sistematis dengan kerangka kerja sebagai berikut.

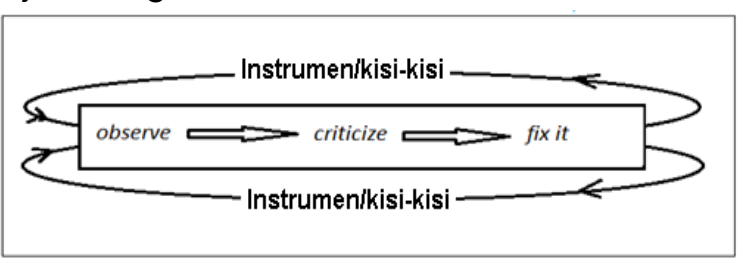

Gambar: Alur pendampingan pola OCF

Pada tahap pertama guru dibawa pada situasi observe. Dalam pemikiran peneliti, observe memberikan kesempatan kepada guru untuk mengamati produk kisi-kisi dan membandingkan kualitasnya dengan pemahaman yang ia miliki. Setelah mengamati guru meng-criticize yaitu mengkritisi produk/kisi-kisi yang diamati. Pada tahapan ini guru tidak hanya dituntut mengkritisi/menemukan kejanggalan, tetapi dituntut juga untuk fix it, atau memperbaiki kesalahan hingga menjadi produk yang benar sesuai ketentuan. Dengan cara ini diharapkan suasana belajar guru lebih menantang, inspiratif dan kreatif.

\section{METODE}

Penelitian dengan subyek guru-guru SDN Yanti Jogoroto yang berjumlah 9 orang ini pada garis besarnya menggunakan penelitian rancangan model Kemmis yang terdiri atas empat langkah, yakni: perencanaan, pelaksanaan, observasi dan refleksi. Pemilihan model didasarkan pada kesesuaian antara permasalahan dengan tindakan yang seharusnya dilakukan. 


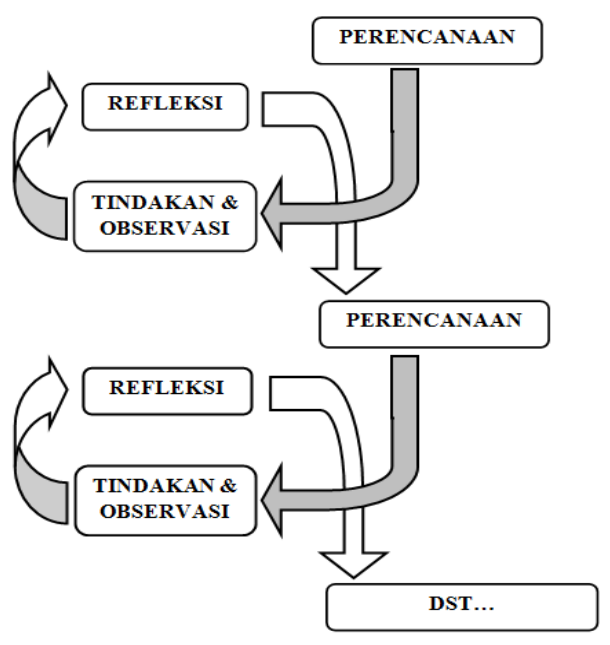

Gambar 2. Langkah Penelitian PTK

Gambar di atas menggambarkan tindakan bersiklus sebagaimana yang telah dilakukan peneliti. Peneliti menerapkan teknik pendampingan pola OCF secara terintegrasi pada setiap siklusnya. Fokus penilaian adalah bagaimana guru melakukan observasi, mengkritisi, dan seberapa kualitas hasil penyempurnaan yang telah dilakukan. Data diambil melalui penilaian terhadap hasil akhir kisi-kisi yang kemudian diolah hingga didapat data akhir untuk mengambil kesimpulan. Data diolah dengan menghitung rata-rata capaian setiap guru pada setiap aspek kemudian dirata-rata. Hasil nilai rata-rata setiap guru dikumpulkan untuk memeroleh nilai rata-rata lembaga. Untuk menentukan niai guru secara perorangan menggunakan rumus berikut:

$N A G=\frac{A 1+A 2+\cdots+A 16}{16} \times 100$

$\mathrm{NAG}=$ Nilai akhir guru

A1 = Aspek ke 1

A2 = Aspek ke 2, dst.

16 = skor maksimal

$100=$ pengali untuk menghasilkan nilai skala $0-100$

Sedangkan untuk menghitung nilai lembaga dengan rumus:

$N A L=\frac{\sum G 1+G 2+\cdots+G 9}{9} \times 100$

$\mathrm{NAL}=$ Nilai akhir lembaga

G1 = Guru ke 1

G2 = Guru ke 2, dst.
$9=$ Skor maksimal

$100=$ pengali untuk menghasilkan nilai skala $0-100$

\section{HASIL DAN PEMBAHASAN}

Tujuan penelitian ini adalah memeroleh gambaran kemampuan guru SDN Yanti Jogoroto dalam menyusun kisi-kisi soal. Penilaian mencakup sebanyak 16 aspek yang dituangkan dalam instrument penilaian kisikisi, dimana setiap aspek mengacu pada prinsip dan indikator penyusunan kisi-kisi.

\section{Siklus I}

Kegiatan diawali dengan perencanaan yang mengacu pada prinsip efektifias dan efisiensi kegiatan. Pada tahap ini peneliti melakukan persiapan dalam bentuk: mengumpulkan guru melalui undangan kepala sekolah. menyusun jadual kegiatan memuat hari, tanggal, kegiatan, jam, dan tempat, menyiapkan materi kegiatan, menyiapkan instrumen observasi, menyiapkan perangkat pendukung seperti LCD, sound, daftar hadir, berita acara, dll.

Pada tahap pelaksanaan guru bersama peneliti melakukan aktivitas sesuai kesepakatan yaitu kegiatan bimbingan teknis penyusunan kisi-kisi yang dilakukan menggunakan konsep pendampingan berpola OCF. Sebelum kegiatan dimulai kepala sekolah mengundang guru untuk berkumpul membahas agenda kegiatan dibarengi dengan Tanya jawab dan diskusi. Agenda pembahasan adalah kendala dalam menyusun kisi-kisi. Pada kegiatan ini peneliti memperoleh data kendala yang dihadapi guru, diantaranya: guru sudah terbiasa memakai kisi-kisi dari orang lain, guru belum memahami kisi-kisi yang sesuai dan tidak, komponen kisikisi sering tidak sama antara satu sumber dengan sumber lain.

Pada kegiatan observe guru diminta melakukan pengamatan terhadap sebuah kisikisi dan mencocokkan dengan standar yang ada. Pada kegiatan ini kepala sekolah selaku peneliti menjelaskan setiap aspek penilaian kisi-kisi kepada guru. Pembahasan meliputi kesesuaian antara kisi-kisi dengan aspek pada instrumen kisi-kisi penilaian. 
Tahap criticize merupakan tahap lanjutan setelah observe. Pada tahap ini guru diminta untuk menerapkan pola pikir kritis dalam mengamati kisi-kisi soal. Guru diharapkan mampu mengkritisi setiap nomor indikator soal pada kisi dengan memperhatikan setiap aspek yang telah dipelajari. Setiap temuan dijadikan bahan melangkah pada tahap selanjutnya yaitu Fix it. Pada tahap ini guru diminta menyempurnakan kisi-kisi, item demi item soal. Setiap guru diharapkan melakukan penyempurnaan pada setiap item yang telah dikritisi. Pada tahap ini kepala sekolah mengkaji hasil penyempurnaan yang telah dilakukan guru dan menyampaikan hasil kajian kepada semua guru. Pada tahap ini pula guru bersama kepala sekolah melakukan refleksi atas apa yang telah dilakukan selama satu tahap tindakan. Sebagai bukti otentik keberhasilan tindakan, guru diminta untuk menyusun kisi-kisi sesuai dengan mengacu pada instrument penilaian kisi-kisi yang sudah dipelajari kemudian dinilai. Nilai hasil penyusunan kisi-kisi setelah dilakukan tindakan pada siklus I disajikan pada diagram berikut:

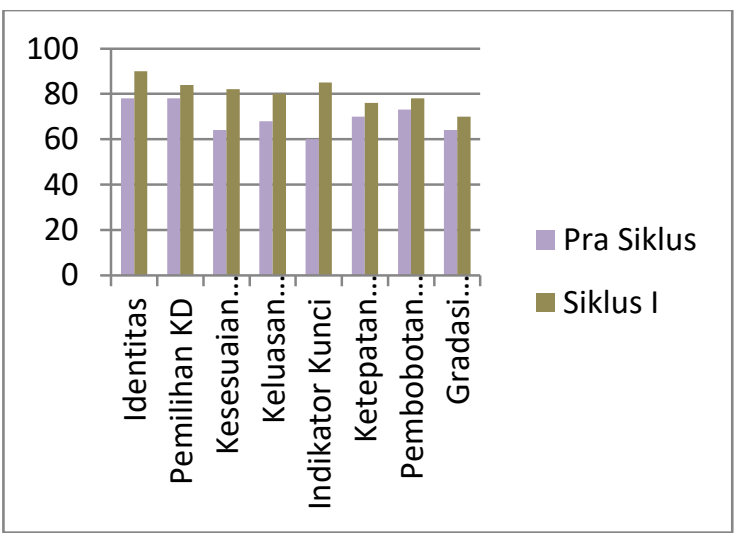

Diagram 1. Nilai Penyusunan Kisi-Kisi Siklus I

Diagram menunjukkan terdapat
peningkatan kemampuan guru dalam
menyusun kisi-kisi soal setelah dilakukan
tindakan pada siklus I. (1) Penulisan identitas
pada kisi-kisi sudah lebih lengkap dan jelas
dimana sebelum tindakan nilai pada aspek ini
hanya 78 meningkat menjadi 90 pada siklus I.
(2) Pemilihan KD pada setiap item soal juga mengalami peningkatan dimana sebelum tindakan dilakukan nilai kemampuan guru pada aspek tersebut hanya 78 menjadi 84. (3) Kemampuan guru dalam memilih materi juga mengalami peningkatan dimana pada tindakan siklus I nilai pada aspek tersebut meningkat menjadi 82 dibandingkan sebelumnya yang hanya 64. (4) Kemampuan guru dalam merumuskan indikator juga sudah lebih baik ditunjukkan peningkatan nilai dimana sebelumnya hanya 68 menjadi 80 . Rumusan indikator sudah mencerminkan keadaan dimana soal dapat dibuat lebih dari satu dan tidak mengarah pada kunci jawaban. (5) Kemampuan guru dalam menentukan indikator kunci juga mengalami peningkatan dimana sebelum tindakan nilainya berada pada angka 60 menjadi 85. (6) Kemampuan guru dalam menentukan level soal mengalami peningkatan dimana sebelum tindakan nilainya 70 menjadi 76. Meskipun peningkatannya belum signifikan pada kenyataannya perubahan ke arah lebih baik sudah tampak. (7) Kecermatan guru dalam menetapkan bobot soal pada indikator mengalami peningkatan dimana nilai sebelumnya 73 menjadi 78. (8) Kemampuan menata gradasi soal juga menunjukkan peningkatan dimana sebelum tindakan, nilai berada pada angka 60 menjadi 74 pada tindakan siklus I. Susunan soal sudah mengarah pada gradasi dari yang mudah ke sulit, dari sederhana ke komplek. Data peningkatan rata-rata nilai menunjukkan peningkatan sebanyak 12 angka dimana pada sebelum tindakan nilai akhir sebesar 69 menjadi 81.

Jika dilihat dari hasil capaian secara umum pada pelaksanaan tindakan mengalami peningkatan, tetapi masih terjadi kekurangan pada beberapa aspek yaitu ketepatan menentukan level soal, pembobotan soal, dan gradasi indikator.

\section{Siklus II}

Pada siklus II peneliti mengambil langkah untuk meningkatkan nilai pada semua aspek terutama yang masih belum signifikan peningkatannya. Peneliti mengambil langkah mengubah aktifitas tahap criticize. Pada tahap ini pengkritisan terhadap kisi-kisi dilakukan 
secara kolaborasi berpasangan. Dalam satu pasangan dilakukan aktifitas saling mengingatkan dan saling menguatkan. Hasil tindakan siklus II sebagaimana diagram berikut:

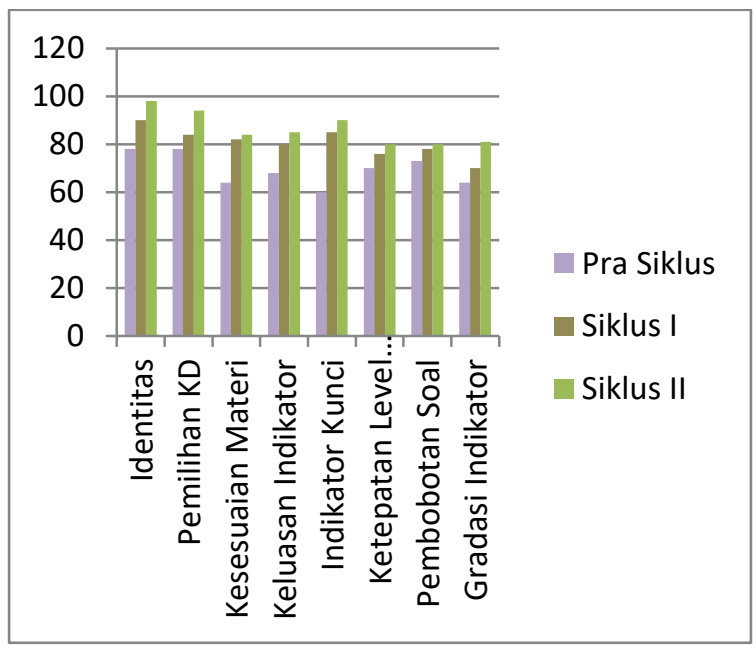

Diagram 2. Nilai Penyusunan Kisi-Kisi Siklus II

Diagram menggambarkan peningkatan nilai guru dalam menyusun kisi-kisi setelah dilakukan tindakan pada siklus II. (1) Pada aspek identitas terjadi peningkatan dimana pada sebelum tindakan nilainya 78 menjadi 90 pada siklus I, dan meningkat menjadi 98 pada siklus II. Pada aspek ini pada prinsipnya guru sudah tidak mengalami masalah hanya sedikit terjadi kesalahan pada penulisan huruf pada identitas tertentu. (2) Pada aspek pemilihan KD juga mengalami peningkatan dimana sebelum tindakan dilakukan nilai hanya 78 menjadi 84 pada siklus I dan meningkat menjadi 94 pada siklus II. (3) Dalam memilih materi kemampuan guru juga mengalami peningkatan dimana pada pras siklus nilai pada aspek ini sebesar 64 menjadi 82 pada siklus I kemudian naik menjadi 84. Pada siklus II. (4) Kemampuan guru dalam merumuskan indikator juga mengalami perkembangan sangat baik dimana sebelumnya hanya 68 menjadi 80 pada siklus I dan meningkat menjadi 85 pada siklus II. (5) Penigkatan kemampuan pada aspek menentukan indikator kunci juga mengalami peningkatan dimana sebelum tindakan nilainya berada pada angka 60 menjadi 85, naik menjadi 90 pada siklus II. (6) Kemampuan guru dalam menentukan level soal mengalami peningkatan dimana sebelum tindakan nilainya 70 menjadi 76 dan naik menjadi 80 pada siklus II. (7) Peningkatan cukup signifikan juga ditunjukkan aspek kemampuan guru dalam menetapkan bobot soal dimana nilai sebelumnya 73 menjadi 78, menjadi 80 pada siklus II. (8) Pada aspek mengkonstruksi gradasi kemampuan guru juga mengalami peningkatan dimana sebelum tindakan, nilai berada pada angka 64 menjadi 70 pada tindakan siklus I. dan naik menjadi 81 pada siklus II. Pada aspek ini indikator soal sudah tertata dengan baik berdasarkan urutan mudah ke sukar dan sederhana ke yang komplek. Data peningkatan rata-rata nilai menunjukkan peningkatan sebanyak 12 angka dimana pada sebelum tindakan nilai akhir sebesar 69 menjadi 81. Berdasarkan hasil capain pada siklus II maka tindakan pendampingan dengan pola OCF sangat berhasil dan sesuai harapan. Dengan demikian tidak perlu tindakan berikutnya.

\section{KESIMPULAN}

Berdasarkan laporan hasil dan pembahasan setelah dilakuan penelitian peningkatan kemampuan guru dalam menyusun kisi-kisi soal tes dengan pola pendampingan OCF dihasilkan kesimpulan bahwa: (1) penerapan pendampingan berpola OCF dalam penyusunan kisi-kisi soal tes terlaksana secara efektif, (2) pola pendampingan dengan teknik OCF mampu meningkatkan kemampuan guru dalam menyusun kisi-kisi soal tes.

\section{SARAN}

Berdasarkan efektifitas dan hasil pada penelitian tersebut maka saran yang dapat disampaikan adalah: perlu dilakukan kegiatan sejenis pada guru-guru pada materi lain agar kompetensi makin Penting bagi sekolah untuk mengalokasikan dana yang cukup demi peningkatan kompetnsi guru secara berkesinambungan. Dinas Pendidikan dan Kebudayaan perlu memfasilitasi terciptakannya iklim regulasi yang lebih mudah agar penelitian lebih banyak dilakukan. 


\section{DAFTAR RUJUKAN}

Ananda, R., \& Fadhilaturrahmi. (2018). Analisis Kemampuan Guru Sekolah Dasar dalam Implementasi Pembelajaran Tematik di SD. Jurnal Basicedu, 2(2), 1121.

Arikunto, S. (2005). Manajemen Penelitian. Jakarta: Rineka Cipta.

Astuti, S., Slameto, \& Y, D. (2017). Peningkatan Kemampuan Guru Sekolah Dasar dalam Penyusunan Instrumen Ranah Sikap melalui In House Training. Kelola, 4(1), 37-47.

Azwar, S. (2015). Sikap Manusia: Teori dan Pengukurannya. Yogyakarta: Pustaka Pelajar.

Fahdini, R., Mulyadi, E., Suhandani, D., \& Julia. (2014). Identifikasi Kompetensi Guru sebagai Cerminan Profesionalisme Tenaga Pendidik di Kabupaten Sumedang. Mimbar Sekolah Dasar, 1(1), 33-42.

Fauziah, Y. . (2011). Analisis Kemampuan Guru dalam Mengembangkan Keterampilan Berpikir Kreatif Siswa Sekolah Dasar Kelas V pada Pembelajaran Ilmu Pengetahuan Alam. Khusus, 2(2), 98-106.

Handoko, H. . (1995). Manajemen Personalia dan Sumber Daya Manusia. Yogyakarta: BPFE UGM.

Hartanto, S., \& Purwanto, S. (2019). Supervisi dan Penilaian Kinerja Guru (MPPKS$P K G$ ). Jakarta: Direktorat Jenderal Guru dan Tenaga Kependidikan.

Ismail, M. . (2010). Kinerja dan Kompetensi Guru dalam Pembelajaran. Lentera Pendidikan, 13(1), 44-63.

Kartowagiran, B. (2011). Kinerja Guru Profesional (Guru Pasca Sertifikasi). Cakarawala Pendidikan, 3(3), 463-473.

Leksono, S. ., Rustaman, N., \& Redjeki, S. (2013). Kemampuan Profesional Guru Biologi dalam Memahami dan Merancang
Model Pembelajaran Konservasi Biodiversitas di SMA. Cakarawala Pendidikan, 32(3), 408-419.

Listyawati, M. (2012). Pengembangan Perangkat Pembelajaran IPA Terpadu di SMP. Journal of Innovative Science Education, 1(1), 62-69.

Manullang, M. (1996). Dasar-Dasar Manajemen (19th ed.). Jakarta: Ghalia Indonesia.

Mardapi, D. (2012). Pengukuran Penilaian \& Evaluasi Pendidikan. Yogyakarta: Nuha Litera.

Nurgiyantoro, B. (2004). Penilaian Pembelajaran Sastra Berbasis Kompetensi. Diksi, 1J(1), 91-116.

Suhandani, D., \& Julia. (2014). Identifikasi Kompetensi Guru sebagai Cerminan Profesionalisme Tenaga Pendidik di Kabupaten Sumedang. Mimbar Sekolah Dasar, 1(2), 128-141.

Supriadi, O. (2009). Pengembangan Profesionalisme Guru Sekolah Dasar. Jurnal Tabularasa, 6(1), 27-38.

Thoha, M. (2004). Perilaku Organisasi: Konsep Dasar dan Aplikasinya. Jakarta: PT Raja Grafindo Persada.

Wardani, I. (2013). Pemantapan Kemampuan Profesional (PKP). Jakarta: Universitas Terbuka.

Wardhani, S. (2008). Apakah Rumusan Indikator pada Silabus dan RPP Anda sudah Baik? Limas, 20, 11-17.

Werdayanti, A. (2008). Pengaruh Kompetensi Guru dalam Proses Belajar Mengajar di Kelas dan Fasilitas Guru terhadap Motivasi Belajar Siswa. Jurnal Pendidikan Ekonomi, 3(1), 79-92.

Widoyoko, E. . (2012). Teknik Penyusunan Instrumen Penelitian. Yogyakarta: Pustaka Pelajar. 